\title{
«Læger på alle gatehjørner»
}

I Tidsskriftet nr. 3/1923 er det en bekymringsmelding - det utdannes for mange leger! Årsaken til den store interessen for studiet tilskriver forfatteren «den store indtægt som følge av den store sykelighet siden influenzaens dager i 1918». På få år var altså situasjonen snudd, og selv i de fjerneste strøk var det god tilgang på legetjenester. Det er ikke bekymring for mulig arbeidsløshet som er begrunnelsen for hans forslag om adgangsbegrensning til studiet - det er sviktende inntjening på grunn av «det stadig økende tal av dem, som skal dele» (Tidsskr Nor Lægeforen 1923; 43: 137-8). I våre dager er det vel ingen som har økonomiske motiver for å søke medisinstudiet?

\section{Advarsel mot det medicinske studium.}

\author{
Av C. Hafstad, Kristiania.
}

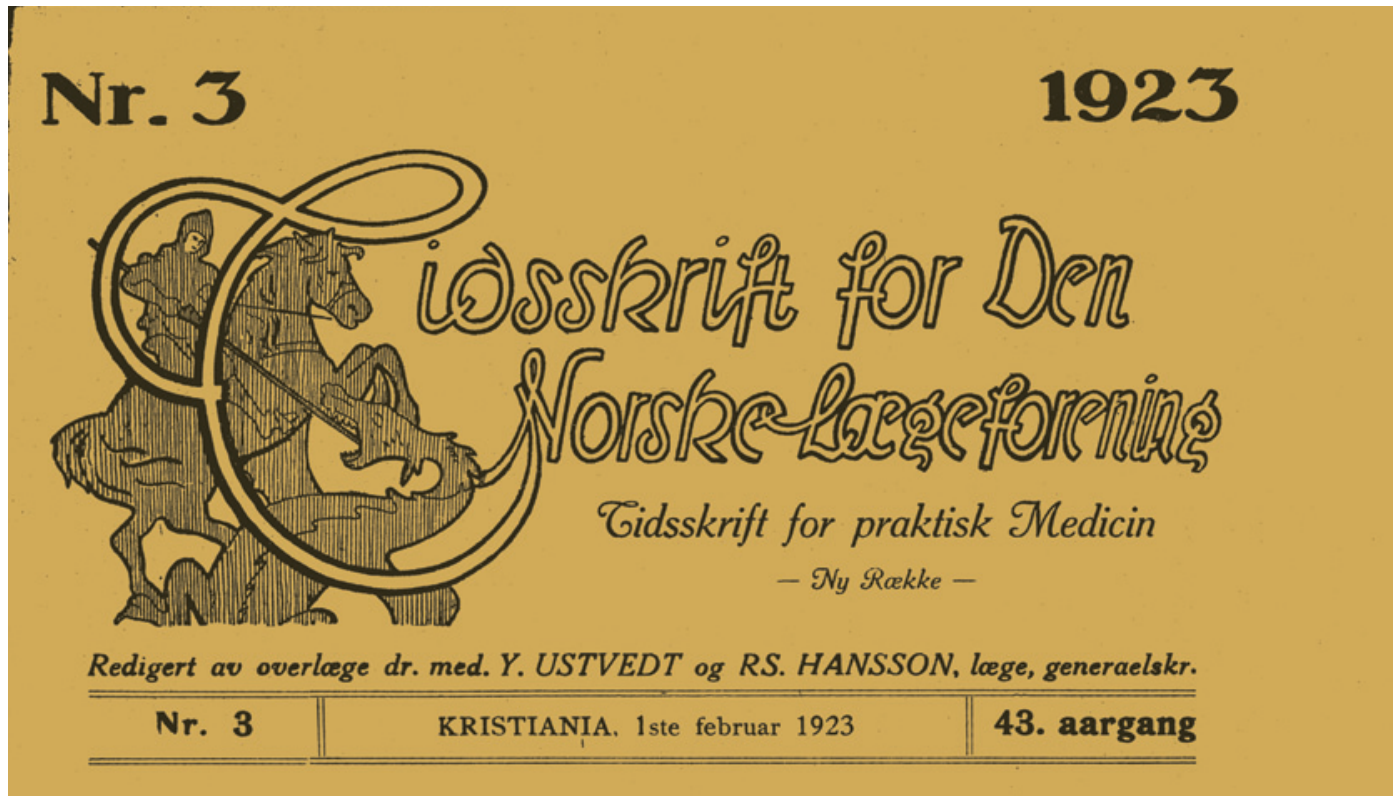

Meget hyppig melder avertissementer i Kristianiaaviserne, at N. N. fra den og den datum agter at begynde praksis i den og den gate. Selv i utkanterne av Kristiania by vrimler det nu av læger på alle gatehjørner.

Læser man listen over søkerne til distriktslægestillingerne, saa er det ogsaa der den samme vrimmel. Mens der for faa aar siden ikke var nogen søker til de fjernereliggende og mest slitsomme poster, er der nu ogsaa til disse poster flere søkere til hver stilling. Der er altsaa baade paa land og i by fuldt op av læger, eller blir det ihvertfald temmelig snart.

Aarsakerne til, at saa mange i de siste aar har følt kald til at bli læger, er vel kjendt. Det er for en ikke ringe del den store indtægt som følge av den store sykelighet siden influenzaens dager i 1918 og den lette adgang til lægehjælp, og det er for det andet det store feilgrep: oprettelsen av store statsstipendier for at lokke ungdom til at studere medicin. Hvad angaar indtægten, kan den nu skrives ned med mindst 40 pct., takket være de økonomiske nedgangstider og det stadig økende tal av dem, som skal dele. Hvad de store stipendier angaar, er det høist besynderlig, at de ikke nu inddrages, saa tilgangen kan begrænses.
Likesaa opstivende som det er for os almindelige læger at ha fulde venteværelser, likesaa stimulerende er det naturligvis for Universitetets lærere at ha fuldt besatte auditorier og laboratorier. Men da jeg ihøst i aviserne leste prof. Schreiners og prof. Mohrs klagerop over de sprængte høre- og læsesaler, maatte jeg virkelig smile - : hvad skal vort lille land med den masseproduktion av læger, - er det muligens ment som eksportartikkel ? Forstod jeg ikke feil; maatte der bydes bedre vilkaar, d. e. bygges saa stort, saa helst al ungdom kunne komme tilbunds i anatomien. En praktisk mand vil si: begræns tilgangen til studiet og gjør det fort. Det er kjendt nok, at kaldet til teknisk studium forsvandt, da tiderne blev daarligere for ingeniørene. Det samme er tilfeldet med kaldet til det juridiske studium. Nu er det medicinen ungdommen har «kald» til, saalænge der troes og vidnes, at indtægterne er glimrende. Jeg vil foreslaa, at det medicinske fakultet regner ut, hvor mange læger der bør utdannes pr. aar for at behovet kan bli dækket, - det kan ikke være vanskelig i vort tyndtbefolkede og let oversigtlige land - og saa tvinge igjennem begrænsning av tilgangen i overensstemmelse hermed - paa samme maate som tilgangen til tandlægestudiet er begrænset.

Kristiania, 4de januar 1923. 